\title{
Molecular basis of cross-resistance in Sagittaria trifolia L. against acetolactate-synthase inhibitors
}

\author{
Danni $\mathrm{Fu}^{\mathrm{a}, \mathrm{c}}$, Bochui Zhao ${ }^{\mathrm{b}, \mathrm{c}}$, Xiuwei $\mathrm{Li}^{\mathrm{c}}$, Songhong Wei ${ }^{\mathrm{c}}$, Mingshan $\mathrm{Ji}^{\mathrm{c}, *}$ \\ a Inner Mongolia University for Nationalities, Tongliao 028000 China \\ b Institute of Cereal and Oil Crops, Hebei Academy of Agriculture and Forestry Sciences, Shijiazhuang \\ 050035 China \\ c College of Plant Protection, Shenyang Agricultural University, Shenyang 110866 China
}

*Corresponding author, e-mail: biops2016@163.com

Received 13 Aug 2019

Accepted 11 Jul 2020

\begin{abstract}
Herbicide resistance to sulfonylureas in Sagittaria trifolia L. is a common problem in northern China. In our study, we used whole-plant dose-response, acetolactate synthase (ALS) sequencing, and ALS enzyme activity methods to assess 3 putative resistant (LN-1, LN-2, and LN-3) and one susceptible (S) S. trifolia populations for crossresistance to ALS inhibitors (bensulfuron-methyl, ethoxysulfuron, pyrazosulfuron-ethyl, penoxsulam, pyribenzoxim, and bispyribac-sodium). Regarding the whole-plant dose-response and the in vitro ALS assays, the results showed that the LN-2 population evolved cross-resistance to all herbicides tested whereas the other two populations showed crossresistance only to bensulfuron-methyl, ethoxysulfuron, pyrazosulfuron-ethyl, and penoxsulam. Results of the in vitro ALS assays were consistent with whole-plant dose-response data. The DNA sequencing of the ALS gene showed that LN-1 and LN-3 populations had a single nucleotide polymorphism in the Pro 197 codon, resulting in the substitution of proline (Pro) by serine (Ser) and leucine (Leu), respectively. However, the LN-2 population showed single nucleotide polymorphism in the second position of the Asp 376 codon, causing substitution of aspartic acid (Asp) by glutamic acid (Glu). The cross-resistance of the $S$. trifolia population to all ALS inhibitors due to Asp 376 mutation in the ALS gene of this species is reported for the first time.
\end{abstract}

KEYWORDS: target-site mutation, genetic analysis, sulfonylurea, triazolopyrimidine, pyrimidinyl-thiobenozoate

\section{INTRODUCTION}

Sagittaria trifolia $\mathrm{L}$. is a perennial aquatic plant that belongs to the Alismataceae family [1]. It is one of the most common and problematic weeds in the rice paddy fields of the northeast China (Fig. S1) [2]. It is self-compatible species, which reproduces mainly vegetatively by corms, but can also reproduce sexually through seeds $[1,2]$. Sulfonylurea (SU) herbicides are used regularly to control $S$. trifolia in China. Unfortunately, strong selection for resistant populations has resulted from the extensive use of these herbicides over the last 15 years [2].

Resistance to acetolactate synthase (ALS) inhibitors, the most common form of herbicide resistance in the world, has rapidly increased since the first reported case in 1984 [3]. Indeed, resistance to ALS inhibitors has been reported for 159 different weed species [4]. Two primary mechanisms cause herbicide resistance in weeds. First, nontarget-site resistance (NTSR) can confer resistance to a range of herbicides with different target pro- teins $[5,6]$. Secondly, target-site resistance (TSR) is mainly dominant to be inherited [7]. Five different chemical classes of herbicides act to inhibit ALS as follows: SU, imidazolinone (IMI), triazolopyrimidine (TP), pyrimidinyl-thiobenozoate (PTB), and sulfonylamino-carbonyl-triazolinone (SCT) [8-11]. Eight mutation sites endowing TSR to ALS inhibitors have been reported as follows: Ala 122 (Domain C), Pro 197 (Domain A), Ala 205 (Domain D), Asp 376 (Domain B), Arg 377 (Domain B), Trp 574 (Domain B), Ser 653 (Domain E) and Gly 654 (Domain E) $[12,13]$ with Pro 197 being the most common site for substitution conferring resistance to SU herbicides [4]. For example, the mutation of the ALS gene at Pro197 alters herbicide target site, resulting in resistance in several ALSresistant populations of Papaver rhoeas L. (common poppy) [14]. A Myosoton aquaticum L. (water chickweed) population showed a Pro-197-Glu amino acid substitution with broad-spectrum resistance across ALS inhibitors [15]. In the research of S. trifolia, 
Iwakami et al [16] reported that a $S$. trifolia population was highly resistant to bensulfuron-methyl and pyrazosulfuron-ethyl resulting from a Pro-197Ser amino acid substitution of ALS in Japan. In addition, the study in $S$. trifolia resistant populations from China identified a new mutation conferring Pro-197-Leu amino acid substitution, which was resistant to bensulfuron-methyl [2].

Cross-resistance occurs when the genetic trait that made the weed species resistant to one herbicide also makes it resistant to other herbicides with the same mechanism of action [17]. Generally, ALSresistance mutations at position 197 (Pro) confer SU and TP resistance, mutations at position 122 (Ala), 205 (Ala), 653 (Ser), or 654 (Gly) confer IMI resistance, and mutations at position 376 (Asp), 377 (Arg) or 574 (Trp) confer broad-spectrum resistance across all ALS herbicides [18]. For instance, the mutation of Pro-197-Ala or -Ser of the ALS is responsible for the high cross-resistance of Cyperus difformis L. (smallflower umbrella sedge) populations to azimsaulfuron and halosulfuron-methyl [19]. A mutation at position 376 from Asp to Glu in Lolium perenne L. (perennial ryegrass) has led to resistance to such ALS inhibitors as TP, SU, and SCT herbicides [20]. Imazamox-resistant Oryza sativa L. (red rice) exhibited cross-resistance to imazethapyr because of TSR and, in particular, a point mutation at the Ser 653 codon [21]. Additionally, crossresistance to SU herbicides has been reported in S. trifolia in our previous study, resulting from Pro to Ser, His, Leu, and Thr substitutions at amino acid position 197 in the ALS gene [22].

SU has been used frequently to control $S$. trifolia and, as a consequence, resistance is now widespread in China [22]. Cross-resistance experiments on $S$. trifolia provide effective herbicide rotations for controlling the resistance population. The objectives of our research were as follows: (1) to elucidate the resistance trait and determine the level of cross-resistance to most frequently used ALS inhibitors in S. trifolia populations by applying wholeplant dose-response experiments; (2) to determine the molecular basis of TSR in S. trifolia; and (3) to measure the in vitro ALS activity extracted from 1 susceptible (S) and 3 resistant (LN-1, LN-2, and LN-3) S. trifolia populations.

\section{MATERIALS AND METHODS}

\section{Plant materials}

Corms of susceptible (S) and putative resistant (R) populations (LN-1, LN-2, and LN-3) were collected in May 2017 from the northeastern region of China (Table S1). The S population was collected from a pond of Shenyang, Liaoning Province, which was never treated with herbicides. The putative R populations were collected from paddy fields where bensulfuron-methyl had been used for more than 10 years. The corms were planted into $25 \mathrm{~cm}$ diameter plastic pots containing moist clay loam soil at a depth of $3.0 \mathrm{~cm}$. These pots were kept in climate chamber at $25 \pm 5.0^{\circ} \mathrm{C} / 14 \pm 5.0^{\circ} \mathrm{C}$ day/night and 14-h photoperiod. Natural light was supplemented by $900 \mu \mathrm{mol} \mathrm{m} \mathrm{s}^{-1}$ photosynthetic photon-flux density from high pressure sodium lamps.

For each putative R population, 20 plants were treated with bensulfuron-methyl (the recommended doses, $30 \mathrm{~g}$ a.i.ha ${ }^{-1}$, which was applied with a cabinet sprayer using a flat fan nozzle delivering $118 \mathrm{~L} \mathrm{ha}^{-1}$ at a pressure of $0.29 \mathrm{MPa}$ positioned $50 \mathrm{~cm}$ above the foliage at the two- to three- leaf stage. At 21 days after treatment, all plants of $R$ populations survived. Then, plants were evaluated for ALS mutation (described in Molecular basis of resistance). After ALS gene sequencing, 18 plants of $\mathrm{LN}-1$ population, 15 of LN-2, and 16 of LN-3 showed amino acid substitutions of Pro-197-Ser, Asp-376-Glu, and Pro-197-Leu, respectively. Respective 15 mutated plants of LN-1, LN-2, and LN-3 populations were collected and grown in 3 separate climate chambers (described above). The corms that were produced by all plants were collected in October 2017, and the harvested corms were used for the following experiments.

\section{Response to ALS inhibitors}

The whole-plant dose-response experiments were conducted to determine the resistance levels and cross-resistance patterns. S. trifolia seedlings were grown in the climate chamber as described above. Seedlings were thinned to 4 plants per pot (3.0to $5.0-\mathrm{cm}$ water depth) before herbicide treatment. Plants were treated with ALS inhibitors at the two- to three- leaf stage, which was applied with the cabinet sprayer as described above. The recommended doses of bensulfuron-methyl, pyrazosulfuron-ethyl, ethoxysulfuron, penoxsulam, pyribenzoxim, and bispyribac-sodium were 30,20 , 13.5, 30, 45, and $37.5 \mathrm{~g}$ a.i.ha ${ }^{-1}$, respectively (Table S2). Bensulfuron-methyl was applied at 0, $7.5,30,120,480,1920$, and $2400 \mathrm{~g}_{\text {a.i.ha }}{ }^{-1}$ to the $\mathrm{R}$ populations and at $0,0.048,0.24,1.2,6,30$, and $150 \mathrm{~g}$ a.i.ha ${ }^{-1}$ to the $\mathrm{S}$ population; pyrazosulfuronethyl was applied at $0,1.25,5,20,80$, and $320 \mathrm{~g}$ a.i.ha ${ }^{-1}$ to the $\mathrm{R}$ populations and at $0,0.31,1.25$, 
5.00, 20, and $80 \mathrm{~g}$ a.i.ha ${ }^{-1}$ to the $\mathrm{S}$ population; ethoxysulfuron was applied at $0,3.38,13.5,54$, 216 , and $864 \mathrm{~g}$ a.i.ha ${ }^{-1}$ to the $\mathrm{R}$ populations and at $0,0.84,3.38,13.5,54$, and $216 \mathrm{~g}$ a.i.ha ${ }^{-1}$ to the $S$ population; penoxsulam was applied at $0,0.47$, $1.88,7.5,30$, and $120 \mathrm{~g}$ a.i.ha ${ }^{-1}$ to both $\mathrm{R}$ and $\mathrm{S}$ populations; pyribenzoxim was applied at $0,0.7$, $2.81,11.25,45$, and $180 \mathrm{~g}$ a.i.ha ${ }^{-1}$ to both $\mathrm{R}$ and $\mathrm{S}$ populations; and bispyribac-sodium was applied at $0,0.59,2.34,9.38,37.5$, and $150 \mathrm{~g}$ a.i.ha ${ }^{-1}$ to both $\mathrm{R}$ and $\mathrm{S}$ populations. Dry weights (oven dried at $70^{\circ} \mathrm{C}$ for $72 \mathrm{~h}$ ) of $S$. trifolia shoots at soil level were determined $21 \mathrm{~d}$ after treatment. The experiments were conducted twice, and there were 3 replicatepots for each herbicide concentration.

\section{Molecular basis of resistance}

Genomic DNA extraction. Genomic DNA was extracted from fresh leaf tissue of the $\mathrm{S}$ (no herbicide application) and $\mathrm{R}$ populations (survived at $30 \mathrm{~g}$ a.i.ha ${ }^{-1}$ bensulfuron-methyl) using the DNAsecure Plant Kit (TIANGEN Biotech, Beijing, China). Ten individual plants of each population were used for DNA extraction.

ALS gene amplification. Polymerase chain reaction (PCR) amplification was performed at a final volume of $25 \mu \mathrm{l}$ with $1.0 \mu \mathrm{l}$ of genomic DNA (60 ng/ $\mu \mathrm{l}), 10 \mu \mathrm{M}$ primer (1.0 $\mu \mathrm{l}$ each) (Table S3), $12.5 \mu 12 \times$ Es Taq MasterMix (Dye) (CWBIO, Beijing, China) and $\mathrm{ddH}_{2} \mathrm{O}$ added to make up the final volume. PCR was performed using the following conditions: $4.0 \mathrm{~min}$ at $94^{\circ} \mathrm{C}, 35$ cycles of $30 \mathrm{~s}$ at $94^{\circ} \mathrm{C}, 30 \mathrm{~s}$ at annealing temperature (Table S3), and $90 \mathrm{~s}$ at $72{ }^{\circ} \mathrm{C}$, followed by $10 \mathrm{~min}$ at $72^{\circ} \mathrm{C}$.

Molecular cloning, plasmid purification, and sequencing. PCR products were visualized by electrophoresis on $1.0 \%$ (wt/vol) agarose gel running in $0.5 \times$ tris/borate/ethylenediaminetetraacetic acid buffer and purified using the SanPrep Column DNA Gel Extraction Kit (Sangon Biotech, Shanghai, China) following the manufacturer's instructions. The pUT-T Cloning Kit (Sangon Biotech, Shanghai, China) was used to clone the desired PCR bands, after which the recombinant plasmids were introduced into DH5a-competent Escherichia coli (Sangon Biotech, Shanghai, China). Positive clones were sequenced in the forward and reverse direction (Sangon Biotech, Shanghai, China). Ten plants of each population were analyzed for mutations by sequencing 5 clones from each plant. Sequence alignments for the detection of the comparison of the ALS gene were performed with the Basic Local Alignment Search Tool (BLAST,
NCBI, Bethesda, MD, USA) and DNAMAN 8.0 (Lynnon Biosoft, Quebec, Canada).

\section{In vitro ALS activity assay}

S. trifolia seedlings were grown in the climate chamber as described above, and leaf materials (not including the petiole) were collected up to the threeto four-leaf stage, snap frozen in liquid nitrogen, and stored at $-80^{\circ} \mathrm{C}$. The in vitro ALS activity assay was determined according to the methods described previously $[22,23]$.

The total protein concentration in the reaction mixture was normalized to $320 \mu \mathrm{g}$ for all samples. Each of ALS inhibitors was dissolved in $1.0 \mathrm{ml}$ acetone and then diluted to a series of solutions. Desalted enzyme extract was assayed with ALS inhibitors at active ingredient concentrations of 0 , $0.01,0.1,1,10,100$, and $1000 \mu \mathrm{M}$ for the 3 $\mathrm{R}$ populations, and $0,0.001,0.01,0.1,10$, and $100 \mu \mathrm{M}$ for the S population [18]. All assays were performed with 3 replicate samples per herbicide dose and performed twice for each population.

\section{Statistical analysis}

Data obtained from the whole-plant dose-response experiments and ALS activity assays were analyzed using analysis of variance (SPSS 21.0; IBM Corp., Armonk, NY, USA) and $t$-tests $(p<0.05)$ to determine the existence of possible significant differences among the populations and the herbicides studied. The ANOVA showed no significant difference between the 2 run experiments, and the data were pooled. Dose-response curves were obtained by a non-linear log-logistic regression model after Seefeld [24] using SigmaPlot 12.5 (Systat Software, San Jose, CA) as given in Equation (1):

$$
y=c+\frac{d-c}{1+\left(x / \mathrm{ED}_{50}\right)^{b}},
$$

where $y$ represents the percent dry weight or percent enzyme activity (percentage of the untreated control), $x$ is the herbicide concentration, $c$ is the lower limit, $d$ is the upper limit of the curve, $b$ is proportional to the slope around $\mathrm{GR}_{50}\left(\mathrm{I}_{50}\right)$, and $\mathrm{ED}_{50}$ is the herbicide concentration at which $50 \%$ growth $\left(\mathrm{GR}_{50}\right)$ or $50 \%$ enzyme activity $\left(\mathrm{I}_{50}\right)$ is inhibited. The resistance index (RI) for the plant dose-response and the ALS assays was calculated by the following ratio: $\mathrm{GR}_{50}\left(\mathrm{I}_{50}\right)$ resistant/GR $\mathrm{GR}_{50}\left(\mathrm{I}_{50}\right)$ susceptible. 



Fig. 1 Dose-response curves for above-ground dry weights of 1 susceptible (S) and 3 resistant (R) populations (LN-1, LN-2, and LN-3) of $S$. trifolia after treatment with various acetolactate synthase (ALS) inhibitors. (a) bensulfuronmethyl; (b) pyrazosulfuron-ethyl; (c) ethoxysulfuron; (d) penoxsulam; (e) pyribenzoxim; and (f) bispyribac-sodium. Each data point represents the mean \pm SE of 3 replicates. 
Table $1 \mathrm{GR}_{50}$ values of the susceptible (S) and resistant populations (R) LN-1, LN-2, and LN-3 of S. rifolia to ALS inhibitors.

\begin{tabular}{|c|c|c|c|c|c|c|c|}
\hline \multirow{2}{*}{ Herbicide } & \multirow{2}{*}{$\begin{array}{c}\mathrm{S} \\
\mathrm{GR}_{50} \\
\left(\mathrm{~g} \text { a.i.ha }{ }^{-1}\right)\end{array}$} & \multicolumn{2}{|l|}{ LN-1 } & \multicolumn{2}{|l|}{$\mathrm{LN}-2$} & \multicolumn{2}{|l|}{ LN-3 } \\
\hline & & $\begin{array}{c}\mathrm{GR}_{50} \\
\left(\mathrm{~g} \text { a.i.ha }{ }^{-1}\right)\end{array}$ & RI & $\begin{array}{c}\mathrm{GR}_{50} \\
\left(\mathrm{~g} \text { a.i.ha }{ }^{-1}\right)\end{array}$ & RI & $\begin{array}{c}\mathrm{GR}_{50} \\
\left(\mathrm{~g} \text { a.i.ha }{ }^{-1}\right)\end{array}$ & RI \\
\hline Bensulfuron-methyl & $1.60 \pm 0.31$ & $105.80 \pm 71.92$ & 66.12 & $249.54 \pm 89.13$ & 155.96 & $141.95 \pm 46.50$ & 88.72 \\
\hline Pyrazosulfuron-ethyl & $2.02 \pm 0.14$ & $71.04 \pm 6.28$ & 35.17 & $76.79 \pm 9.73$ & 38.01 & $109.23 \pm 19.69$ & 54.07 \\
\hline Ethoxysulfuron & $1.95 \pm 0.08$ & $79.92 \pm 14.73$ & 40.98 & $130.28 \pm 67.24$ & 66.81 & $187.61 \pm 54.54$ & 96.21 \\
\hline Penoxsulam & $2.17 \pm 0.00$ & $6.19 \pm 0.93$ & 2.85 & $8.54 \pm 0.30$ & 3.94 & $15.64 \pm 2.24$ & 7.21 \\
\hline Pyribenzoxim & $2.46 \pm 0.16$ & $4.13 \pm 0.36$ & 1.68 & $7.35 \pm 0.74$ & 2.99 & $3.72 \pm 0.08$ & 1.51 \\
\hline Bispyribac-sodium & $2.26 \pm 0.02$ & $3.77 \pm 0.58$ & 1.67 & $16.87 \pm 1.44$ & 7.46 & $2.73 \pm 0.34$ & 1.21 \\
\hline
\end{tabular}

ALS, acetolactate synthase; $\mathrm{GR}_{50}$, the herbicides concentration at which $50 \%$ growth is inhibited; RI, resistance index. Each value represents the mean \pm standard error.

\section{RESULTS}

\section{Dose-response experiments}

Herbicide dose-response curves of the $S$. trifolia populations are shown in Fig. 1. The 4 populations responded differently to ALS inhibitors. The $\mathrm{GR}_{50}$ values calculated from the dose- response curves confirmed that the 3 suspected R populations ( $\mathrm{LN}-1$, LN-2, and LN-3) were indeed resistant to SU herbicides (bensulfuron-methyl, pyrazosulfuron-ethyl, and ethoxysulfuron) (Fig. 1 and Table 1). The doses of SU herbicides required for $50 \%$ growth reduction in the $\mathrm{R}$ populations were at least 35 times higher than those required to produce the same effect on the $\mathrm{S}$ population. The $3 \mathrm{R}$ populations exhibited different sensitivity to penoxsulam. The RI were 2.85, 3.94, and 7.21 for LN-1, LN-2, and LN-3, respectively. Pyribenzoxim and bispyribacsodium similarly affected all the LN-1, LN-3, and $\mathrm{S}$ populations, denoting that there were no crossresistance to those herbicides; however, the LN-2 population was cross-resistant to those herbicides, which showed RI of 2.99 and 7.46, respectively (Table 1).

\section{Molecular genetic analyses}

The sequences of the ALS gene fragment in S. trifolia were analyzed by BLAST (Fig. 2). The homologies of sequences in the $S$ and $R$ populations were similar to a known ALS gene obtained from $S$. trifolia (GenBank: KC 287227.1) and showed approximately 99.88\% similarity. For the ALS gene of the LN-2 population, a mutation was confirmed at position 376 (Asp). This caused the nucleotide to change from $\mathrm{T}$ to $\mathrm{G}$, resulting in the amino acid Asp (GAT) being replaced with Glu (GAG) (Fig. 3). In addition, there was a single-nucleotide substitution identified in the LN-1 and LN-3 populations that was located at position 197 (Pro). This caused the amino acid Pro (CCC) to be substituted with Ser (TCC) and Leu (CTC), respectively.

\section{ALS assay}

Resistance to ALS inhibitor in S. trifolia was also confirmed at the enzyme level. There was no statistical difference in ALS activity expressed in $\mu \mathrm{mol}$ acetone $\mathrm{h}^{-1} \mathrm{mg}^{-1}$ protein among LN-1, LN-2, $\mathrm{LN}-3$, and $\mathrm{S}$ populations without herbicide (data not shown), which suggests that the enzyme is not overexpressed in the LN-1, LN-2, and LN-3 populations. In vitro studies have shown that LN1, LN-2, and LN-3 populations exhibited significant resistance to SU herbicides (bensulfuron-methyl, pyrazosulfuron-ethyl, and ethoxysulfuron) based on $\mathrm{I}_{50}$ (Fig. 4 and Table 2). The $3 \mathrm{R}$ populations also exhibited resistance to penoxsulam. The RI were $2.30,2.59$, and 3.85 for $\mathrm{LN}-1, \mathrm{LN}-2$, and $\mathrm{LN}-3$ populations, respectively. There was no significant difference in enzyme sensitivity to pyribenzoxim and bispyribac-sodium between LN-1 and LN3 populations. It is demonstrated that the ALS from the LN-2 population was cross-resistant to all herbicides tested whereas the other 2 populations showed ALS with cross-resistance to bensulfuronmethyl, ethoxysulfuron, pyrazosulfuron-ethyl, and penoxsulam (Table 2).

\section{DISCUSSION}

ALS inhibitors, which exhibit excellent efficacy to control broadleaf weeds and sedges in paddy fields, are widely and continuously used; however, more and more weeds are becoming resistant to these herbicides. Some prominent examples are Amaranthus retroflexus L. (redroot amaranth), Descu- 


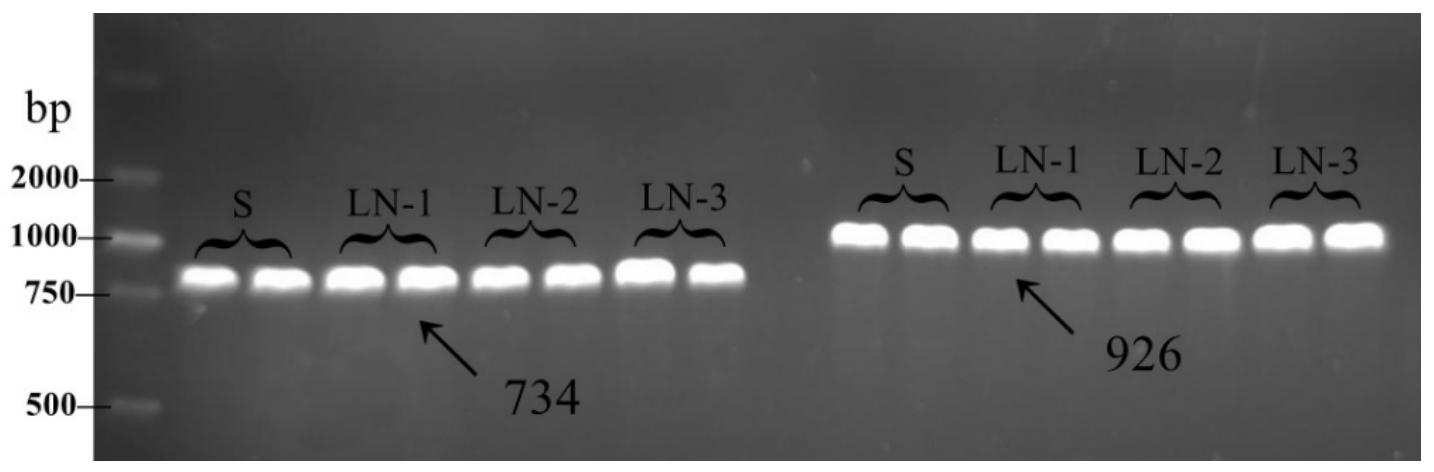

Fig. 2 A part of the amplification result of 1 susceptible (S) and 3 resistant (R) S. trifolia populations (LN-1, LN-2, and LN-3).

\begin{tabular}{|c|c|c|c|c|c|c|c|c|c|c|c|c|c|c|c|}
\hline & & \multicolumn{12}{|c|}{ Domain A } & \multicolumn{2}{|c|}{ Domain B } \\
\hline & & 191 & 192 & 193 & 194 & 195 & 196 & 197 & 198 & 199 & 200 & 201 & 202 & 203 and 376 & 377 \\
\hline \multirow{2}{*}{\multicolumn{2}{|c|}{ Arabidopsis thaliana }} & GCA & ATC & ACA & GGA & CAA & GTC & $\mathrm{CCT}$ & CGT & CGT & ATG & ATT & GGT & $A C A$ & CGT *** \\
\hline & & A & I & $\mathrm{T}$ & G & $\mathrm{Q}$ & v & $\mathbf{P}$ & $\mathrm{R}$ & $\mathrm{R}$ & M & I & G & $T$ T & $\mathrm{R} * * *$ \\
\hline \multirow[t]{2}{*}{ S. trifolia } & $\mathrm{S}$ & GCC & ATC & $\mathrm{ACC}$ & GGC & CAG & GTG & $\mathrm{CCC}$ & CGC & AGG & ATG & ATC & GGC & $A C G$ GAT & CGC \\
\hline & & A & 1 & $\mathrm{~T}$ & G & $\mathrm{Q}$ & $v$ & $\mathrm{P}$ & $\mathrm{R}$ & $\mathrm{R}$ & M & 1 & G & $T$ T & $\mathrm{R} * * *$ \\
\hline \multirow[t]{2}{*}{ S. trifolia } & $\mathrm{LN}-1$ & $\mathrm{GCC}$ & ATC & $\mathrm{ACC}$ & GGC & CAG & GTG & TCC & CGC & AGG & ATG & ATC & GGC & ACG & CGC * \\
\hline & & A & I & $\mathrm{T}$ & G & $\mathrm{Q}$ & v & $s$ & $\mathrm{R}$ & $\mathrm{R}$ & M & I & G & $T$ D & $\mathrm{R} * * *$ \\
\hline \multirow[t]{2}{*}{ S. trifolia } & LN-2 & GCC & ATC & ACC & GGC & CAG & GTG & $\mathrm{CCC}$ & CGC & AGG & ATG & ATC & GGC & $A C G$ *anos $\mathrm{GAG}$ & CGC * \\
\hline & & A & 1 & $\mathrm{~T}$ & G & $\mathrm{Q}$ & v & $\mathrm{P}$ & $\mathrm{R}$ & $\mathrm{R}$ & $M$ & 1 & G & 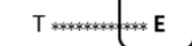 & $R_{* * *}$ \\
\hline \multirow[t]{2}{*}{ S. trifolia } & $\mathrm{LN}-3$ & $\mathrm{GCC}$ & ATC & $\mathrm{ACC}$ & GGC & CAG & GTG & СтC & CGC & AGG & ATG & ATC & GGC & ACG GAT & CGC ** \\
\hline & & A & I & $\mathrm{T}$ & G & Q & v & $\mathbf{L}$ & $\mathrm{R}$ & $\mathrm{R}$ & M & 1 & G & 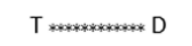 & $R * *$ \\
\hline
\end{tabular}

Fig. 3 Comparison of the regions of the acetolactate synthase (ALS) gene that contained mutations and the amino acid sequences from the resistant and susceptible $S$. trifolia populations. Letters in boxes represent mutations. Reference sequence for nucleotide and codon numbering is the coding sequence of the Arabidopsis thaliana acetolactate synthase (ALS) gene (NM 114714.2).

rainia sophia L. (flixweed), Monochoria korsakowi (moolokzam), and Digitaria sanguinalis L. (large crabgrass) in China, all of which exhibit resistance to ALS inhibitors after several successive applica-

Table $2 \mathrm{I}_{50}$ values of the susceptible (S) and resistant (R) populations, LN-1, LN-2, and LN-3 of S. trifolia, to ALS inhibitors.

\begin{tabular}{|c|c|c|c|c|c|c|c|}
\hline \multirow{2}{*}{ Herbicide } & \multirow{2}{*}{$\begin{array}{c}S \\
I_{50}(\mu M)\end{array}$} & \multicolumn{2}{|c|}{ LN-1 } & \multicolumn{2}{|c|}{ LN-2 } & \multicolumn{2}{|c|}{ LN-3 } \\
\hline & & $\mathrm{I}_{50}(\mu \mathrm{M})$ & RI & $\mathrm{I}_{50}(\mu \mathrm{M})$ & RI & $\mathrm{I}_{50}(\mu \mathrm{M})$ & RI \\
\hline Bensulfuron-methyl & $0.29 \pm 0.06$ & $24.62 \pm 1.73$ & 84.90 & $56.51 \pm 17.90$ & 194.86 & $31.47 \pm 5.16$ & 108.52 \\
\hline Pyrazosulfuron-ethyl & $0.15 \pm 0.02$ & $13.74 \pm 1.63$ & 91.60 & $19.18 \pm 5.87$ & 127.87 & $24.69 \pm 7.00$ & 164.60 \\
\hline Ethoxysulfuron & $0.11 \pm 0.04$ & $9.72 \pm 1.26$ & 88.26 & $17.44 \pm 8.60$ & 158.55 & $20.24 \pm 4.69$ & 184.00 \\
\hline Penoxsulam & $0.27 \pm 0.03$ & $0.62 \pm 0.07$ & 2.30 & $0.70 \pm 0.22$ & 2.59 & $1.04 \pm 0.16$ & 3.85 \\
\hline Pyribenzoxim & $0.23 \pm 0.03$ & $0.40 \pm 0.03$ & 1.74 & $0.88 \pm 0.02$ & 3.83 & $0.39 \pm 0.42$ & 1.56 \\
\hline Bispyribac-sodium & $0.74 \pm 0.10$ & $1.22 \pm 0.59$ & 1.65 & $11.68 \pm 0.91$ & 15.78 & $1.07 \pm 0.07$ & 1.45 \\
\hline
\end{tabular}

ALS, acetolactate synthase; $I_{50}$, the herbicides concentration at which $50 \%$ enzyme activity is inhibited; and RI, resistance index. Each value represents the mean \pm standard error. 

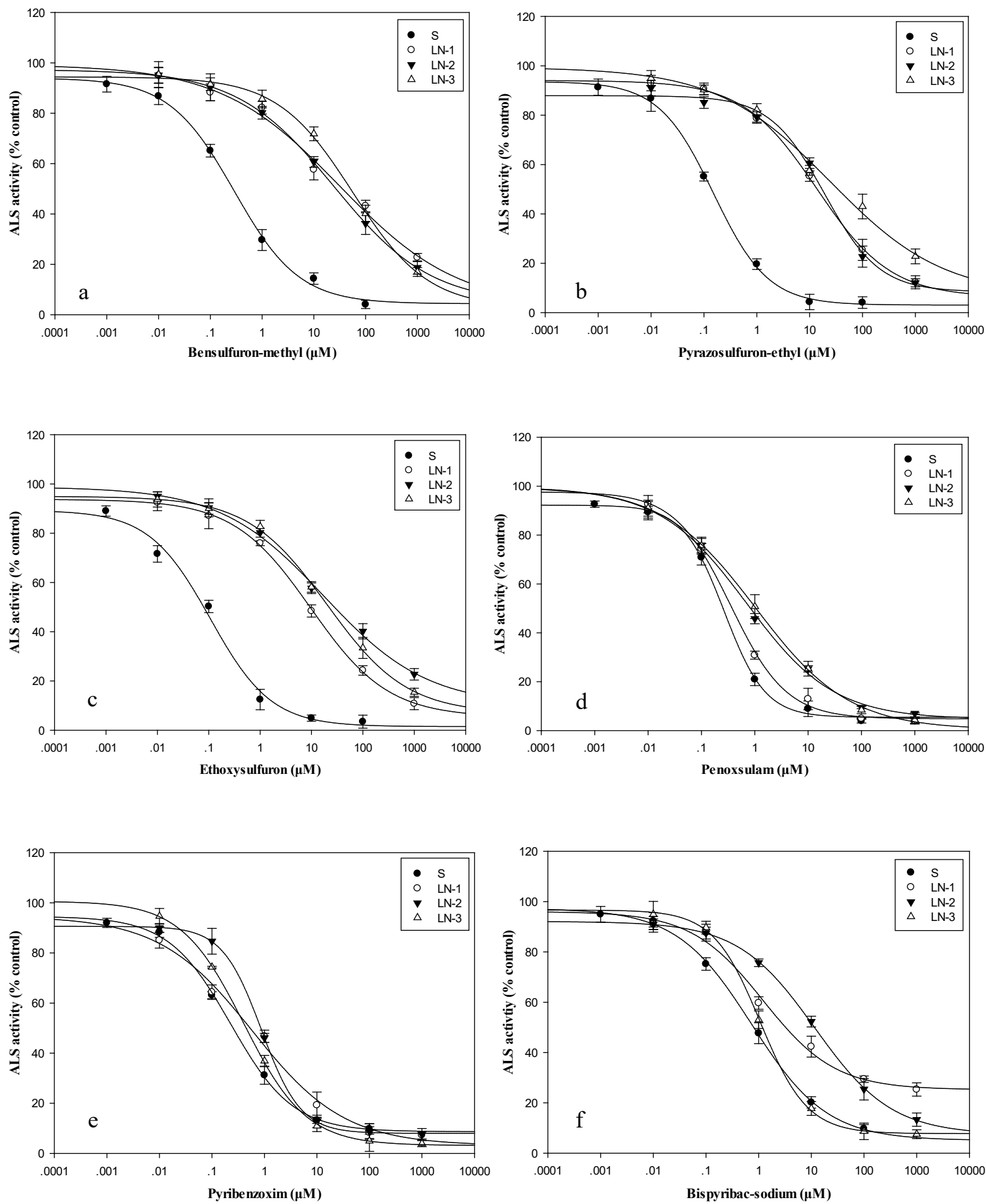

Fig. 4 Inhibition of ALS activity of 1 susceptible (S) and 3 resistant (R) S. trifolia populations (LN-1, LN-2, and LN-3) in the presence of various acetolactate synthase (ALS) inhibitors. (a) bensulfuron-methyl; (b) pyrazosulfuron-ethyl; (c) ethoxysulfuron; (d) penoxsulam; (e) pyribenzoxim; and (f) bispyribac-sodium. Each data point represents the mean $\pm S E$ of the 3 replicates. 
tions [25-28]. In the rice paddy fields, S. trifolia has become the dominant weed species in the northeast of China since 2010, and it has developed resistance to SU herbicides [2].

In this study, whole-plant dose-response assays demonstrated that the $3 \mathrm{R}$ S. trifolia populations exhibited high levels of resistance and were crossresistant to the $3 \mathrm{SU}$ and $1 \mathrm{TP}$ herbicides; however, those populations (except for LN-2) were susceptible to PTB herbicides. The total ALS activity was not different between the $\mathrm{S}$ and $3 \mathrm{R}$ populations, which suggests that the enzyme is not overexpressed in the R populations. Results of the in vitro ALS assays were consistent with wholeplant dose-response data. All $3 \mathrm{R}$ populations used in this study were characterized at the molecular level. The DNA sequencing of the ALS gene showed that LN-1 and LN-3 populations had a mutation in the Pro 197 codon, and the LN-2 population in the Asp 376 codon (Fig. 3). Various ALS herbicide resistances endowing mutations at Pro-197 of the ALS gene have been identified and characterized in several weed species [12, 13,29], including S. trifolia $[2,16]$, and mutations at this position are confirmed to confer high levels of resistance to ALS inhibitors [30]. For instance, Raphanus raphanistrum L. (wild radish) populations homozygous for Pro-197-Ser and Pro-197-Thr were produced to determine cross-resistance to SU and TP, but not to IMI herbicides [18]. Additionally, our previous study has shown that the Pro-197-Ser, Pro197-His, Pro-197-Leu, and Pro-197-Thr mutations were characterized in S. trifolia as conferring highlevel resistance to the SU herbicides [22]. In contrast, the Asp-376 mutation is reported for the first time in S. trifolia. Furthermore, identification of the mutation and the site of mutation appears to help predict the probable levels of resistance and cross-resistance to other ALS inhibitors in S. trifolia. This is very important to provide a basis for the management of resistant populations in the field.

In China, farmers prefer increasing the dose of herbicides to applying alternative herbicides, which may lead to $S$. trifolia cross-resistance to other SU or even to non-SU ALS inhibitors. Although ALS inhibitors will continue to be the most popular and effective option for $S$. trifolia control in many situations, the continued management of weed species where ALS resistance has evolved is dependent on applying herbicides with different modes of action in combination or in rotation. Moreover, efficacious resistance alleviation should be emphasized by decreasing herbicide selection pressure through integrated weed management practices under farm conditions such as crop rotation, deep flooding, and alternation of wet and dry seeded systems.

In conclusion, this research has confirmed the presence of ALS TSR in S. trifolia populations in Liaoning province of China. The Asp-376-Glu mutation was characterized in S. trifolia as conferring cross-resistance to all herbicides tested whereas Pro197-Ser and Pro-197-Leu mutations showed crossresistance only to SU and TP herbicides. Results of the in vitro ALS assays were consistent with wholeplant dose-response data. This is the first time to report the Asp-376-Glu in S. trifolia and characterize these $S$. trifolia populations as cross-resistant to ALS inhibitors.

\section{Appendix A. Supplementary data}

Supplementary data associated with this article can be found at http://dx.doi.org/10.2306/ scienceasia1513-1874.2020.069.

Acknowledgements: The authors sincerely thank Mr. Jamil Shafi, Ms. Chunhui Liu, and Mr. Minlong Wang for their technical assistance in conducting this research. This work was supported by Inner Mongolia University for Nationalities Doctoral Research Initiation Fund (No. BS579) and Special Fund for National Key R\&D Plan (No. 2016YFD0200500).

\section{REFERENCES}

1. Chen JM, Gituru WR, Wang QF (2007) A comparison of the extent of genetic variation in the endangered Sagittaria natans and its widespread congener $S$. trifolia. Aquat Bot 87, 1-6.

2. Wei SH, Li PS, Ji MS, Dong Q, Wang HN (2015) Target-site resistance to bensulfuron-methyl in Sagittaria trifolia L. populations. Pestic Biochem Physiol 124, 81-85.

3. Brown HM, Cotterman JC (1994) Recent advances in sulfonylurea herbicides. In: Chemistry of Plant Protection: Herbicides Inhibiting Branched-Chain Amino Acid Biosynthesis, Vol 10, Springer-Verlag, Berlin Heidelberg, Germany, pp 47-81.

4. Heap IM (2019) International Survey of Herbicide Resistant Weeds. Available at: www.weedscience. com.

5. Cummins I, Moss S, Cole DJ, Edwards R (1997) Glutathione transferases in herbicide-resistant and herbicide-susceptible black-grass (Alopecurus myosuroides). Pest Manag Sci 51, 244-250.

6. Letouzé A, Gasquez J (2001) Inheritance of fenoxaprop-P-ethyl resistance in a blackgrass (Alopecurus myosuroides Huds.) population. Theor Appl Genet 103, 288-296. 
7. Délye C (2005) Weed resistance to acetyl-coenzyme A carboxylase inhibitors: an update. Weed Sci 53, 728-746.

8. Chaleff RS, Mauvais CJ (1984) Acetolactate synthase is the site of action of two sulfonylurea herbicides in higher plants. Sci 224, 1443-1446.

9. Shaner DL, Anderson PC, Studham MA (1984) Imidazolinones: Potent inhibitors of acetohydroxidacid synthase. Plant Physiol 76, 545-546.

10. Gerwick BC, Subramanian MV, Loney-Gallant VI, Chandler DP (1990) Mechanism of action of the 1, 2, 4-triazolo [1, 5-a] pyrimidines. Pestic Sci 29, 357-364.

11. Stidham MA (1991) Herbicides that inhibit acetohydroxyacid synthase. Weed Sci 39, 428-434.

12. Beckie HJ, Tardif FJ (2012) Herbicide cross resistance in weeds. Crop Prot 35, 15-28.

13. Powles SB, Yu Q (2010) Evolution in action: plants resistant to herbicides. Ann Rev Plant Biol 61, 317-347.

14. Rey-Caballero J, Menéndez J, Osuna MD, Salas M, Torra J (2017) Target-site and Non-target-site resistance mechanisms to ALS inhibiting herbicides in Papaver rhoeas. Pestic Biochem Physiol 138, 57-65.

15. Liu WT, Yuan GH, Du L, Guo WL, Li LX, Bi YL, Wang JX (2015) A novel Pro197Glu substitution in acetolactate synthase (ALS) confers broad-spectrum resistance across ALS inhibitors. Pestic Biochem Physiol 117, 31-38.

16. Iwakami $\mathrm{S}$, Watanabe $\mathrm{H}$, Miura $\mathrm{T}$, Matsumoto $\mathrm{H}$, Uchino A (2014) Occurrence of sulfonylurea resistance in Sagittaria trifolia, a basal monocot species, based on target-site and non-target-site resistance. Weed Biol Manag 14, 43-49.

17. Deng W, Cao Y, Yang Q, Liu MJ, Mei Y, Zheng MQ (2014) Different cross-resistance patterns to AHAS herbicides of two tribenuron-methyl resistant flixweed (Descurainia Sophia L.) biotypes in China. Pestic Biochem Physiol 112, 26-32.

18. Yu Q, Han H, Li M, Purba E, Walsh MJ, Powles SB (2012) Resistance evaluation for herbicide resistance-endowing acetoacetate synthase (ALS) gene mutations using Raphanus raphanistrum populations homozygous for specific ALS mutations. Weed Res 52, 178-186.

19. Ntoanidou S, Kaloumenos N, Diamantidis G, Madesis P, Eleftherohorinos I (2016) Molecular basis of Cyperus difformis cross-resistance to ALS-inhibiting herbicides. Pestic Biochem Physiol 127, 38-45.

20. Menegat A, Bailly GC, Aponte R, Heinrich GMT,
Sievernich B, Gerhards R (2016) Acetohydroxyacid synthase (AHAS) amino acid substitution Asp376Glu in Lolium perenne: effect on herbicide efficacy and plant growth. J Plant Dis Pro 123, 145-153.

21. Kaloumenos NS, Capote N, Aguado A, Eleftherohorinos IG (2013) Red rice (Oryza sativa) crossresistance to imidazolinone herbicides used in resistant rice cultivars grown in northern Greece. Pestic Biochem Physiol 105, 177-183.

22. Fu DN, Shafi J, Zhao BC, Li XW, Zhu H, Wei SH, Ji MS (2017) Bensulfuron-methyl resistant Sagittaria trifolia L.: multiple resistance, cross-resistance and molecular basis of resistance to acetolactate synthase-inhibiting herbicides. Arch Biol Sci 69, 649-658.

23. Yu Q, Han H, Vila-Aiub MM, Powles SB (2010) AHAS herbicide resistance endowing mutations: effect on AHAS functionality and plant growth. $J$ Exp Bot 61, 3925-3934.

24. Seefeld SS, Jensen JE, Fuerst EP (1995) Log-logistic analysis of herbicides dose response relationships. Weed Technol 9, 218-227.

25. Lu ZZ, Zhang CX, Fu JF, Li MH, Li GJ (2009) Molecular basis of resistance to bensulfuron-methyl in Monochoria korsakowii. Agr Sci China 42, 3516-3521.

26. Huang, ZF, Chen JY, Zhang CX, Huang HJ, Wei SH, Zhou XX, Chen JC, Wang X (2016) Target-site basis for resistance to imazethapyr in redroot amaranth (Amaranthus retroflexus L.). Pestic Biochem Physiol 128, 10-15.

27. Mei Y, Si C, Liu MJ, Qiu LH, Zheng MQ (2017) Investigation of resistance levels and mechanisms to nicosulfuron conferred by non-target-site mechanisms in large crabgrass (Digitaria sanguinalis L.) from China. Pestic Biochem Physiol 141, 84-89.

28. Deng W, Yang Q, Zhang YZ, Jiao HT, Mei Y, Li XF, Zheng MQ (2017) Cross-resistance patterns to acetolactate synthase (ALS)-inhibiting herbicides of flixweed (Descurainia sophia L.) conferred by different combinations of ALS isozymes with a Pro-197Thr mutation or a novel Trp-574-Leu mutation. Pestic Biochem Physiol 136, 41-45.

29. Tranel PJ, Wright TR (2002) Resistance of weeds to ALS-inhibiting herbicides: what have we learned? Weed Sci 50, 700-712.

30. Kaloumenos NS, Dordas CA, Diamantidis GC, Eleftherohorinos IG (2009) Multiple Pro197 substitutions in the acetolactate synthase of corn poppy (Papaver rhoeas) confer resistance to tribenuron. Weed Sci 57, 362-368. 


\section{Appendix A. Supplementary data}

Table S1 Collection sites of S. trifolia populations.

\begin{tabular}{lccc}
\hline Population & Location & Latitude & Longitude \\
\hline LN-1 & Haicheng, Anshan & $\mathrm{N}: 40^{\circ} 57^{\prime} 53^{\prime \prime}$ & $\mathrm{E}: 122^{\circ} 26^{\prime} 14^{\prime \prime}$ \\
LN-2 & Shenbei, Shenyang & $\mathrm{N}: 42^{\circ} 02^{\prime} 22^{\prime \prime}$ & $\mathrm{E}: 123^{\circ} 21^{\prime} 24^{\prime \prime}$ \\
LN-3 & Dashiqiao, Yingkou & $\mathrm{N}: 41^{\circ} 03^{\prime} 17^{\prime \prime}$ & $\mathrm{E}: 122^{\circ} 21^{\prime} 25^{\prime \prime}$ \\
S & Dongling, Shenyang & $\mathrm{N}: 41^{\circ} 49^{\prime} 36^{\prime \prime}$ & $\mathrm{E}: 123^{\circ} 35^{\prime} 34^{\prime \prime}$ \\
\hline
\end{tabular}

Table S2 Information about the ALS inhibitors used in whole-plant dose-response experiments on S. trifolia populations.

\begin{tabular}{llcll}
\hline Common name & Trade name & Dose $\left(\mathrm{g}\right.$ a.i.ha $\left.{ }^{-1}\right)$ & Content & Manufacturer \\
\hline Bensulfuron-methyl (SU) & Fubao & 30.0 & $30 \% \mathrm{WP}$ & Jiangsu Futian Agrochemical Co., Ltd., China \\
Pyrazosulfuron-ethyl (SU) & Kuaida & 20.0 & $10 \% \mathrm{WP}$ & Jiangsu Kuaida Agrochemical Co., Ltd., China \\
Ethoxysulfuron (SU) & Taiyangxing & 13.5 & $15 \% \mathrm{WG}$ & Bayer cropscience, Beijing, China \\
Penoxsulam (TP) & Daojie & 30.0 & 25\% OF & Clipper, Dow AgroSciences, Beijing, China \\
Pyribenzoxim (PTB) & Pyribenzoxim & 45.0 & $5 \%$ EC & Korea's LG Life Science Co., Ltd., Shanghai, China \\
Bispyribac-sodium (PTB) & Nonglilai & 37.5 & $10 \%$ SC & Meifeng Agrochemical Co., Ltd., China \\
\hline
\end{tabular}

ALS, acetolactate synthase; SU, sulfonylurea; TP, triazolopyrimidine; PTB, pyrimidinyl-thiobenozoate; WP, water power; WG, water dispersible granule; OF, oil flowable; EC, emulsifiable concentrate; and SC, suspension concentrate.

Table S3 Primers used for sequencing of conserved region of acetolactate synthase gene in S. trifolia.

\begin{tabular}{llccc}
\hline Primer & Sequence $\left(5^{\prime}-3^{\prime}\right)$ & $\begin{array}{c}\text { Annealing temperature } \\
\left({ }^{\circ} \mathrm{C}\right)\end{array}$ & $\begin{array}{c}\text { Amplicon size } \\
(\mathrm{bp})\end{array}$ & Targeted mutation site \\
\hline 1 & $\begin{array}{l}\text { F1 AGAGGGAGGGTGTCAAAGACG } \\
\text { R1 TTTCAGGTCGCCACAGATAGAG }\end{array}$ & 64 & 926 & $122,197,205,376,377$ \\
2 & $\begin{array}{l}\text { F2 TCTGTGGCGACCTGAAACTG } \\
\text { R2 ACCTCCACTCGGAATCATCG }\end{array}$ & 62 & 734 & $574,653,654$ \\
\hline
\end{tabular}

$\mathrm{F}$, forward primer and $\mathrm{R}$, reverse primer. 

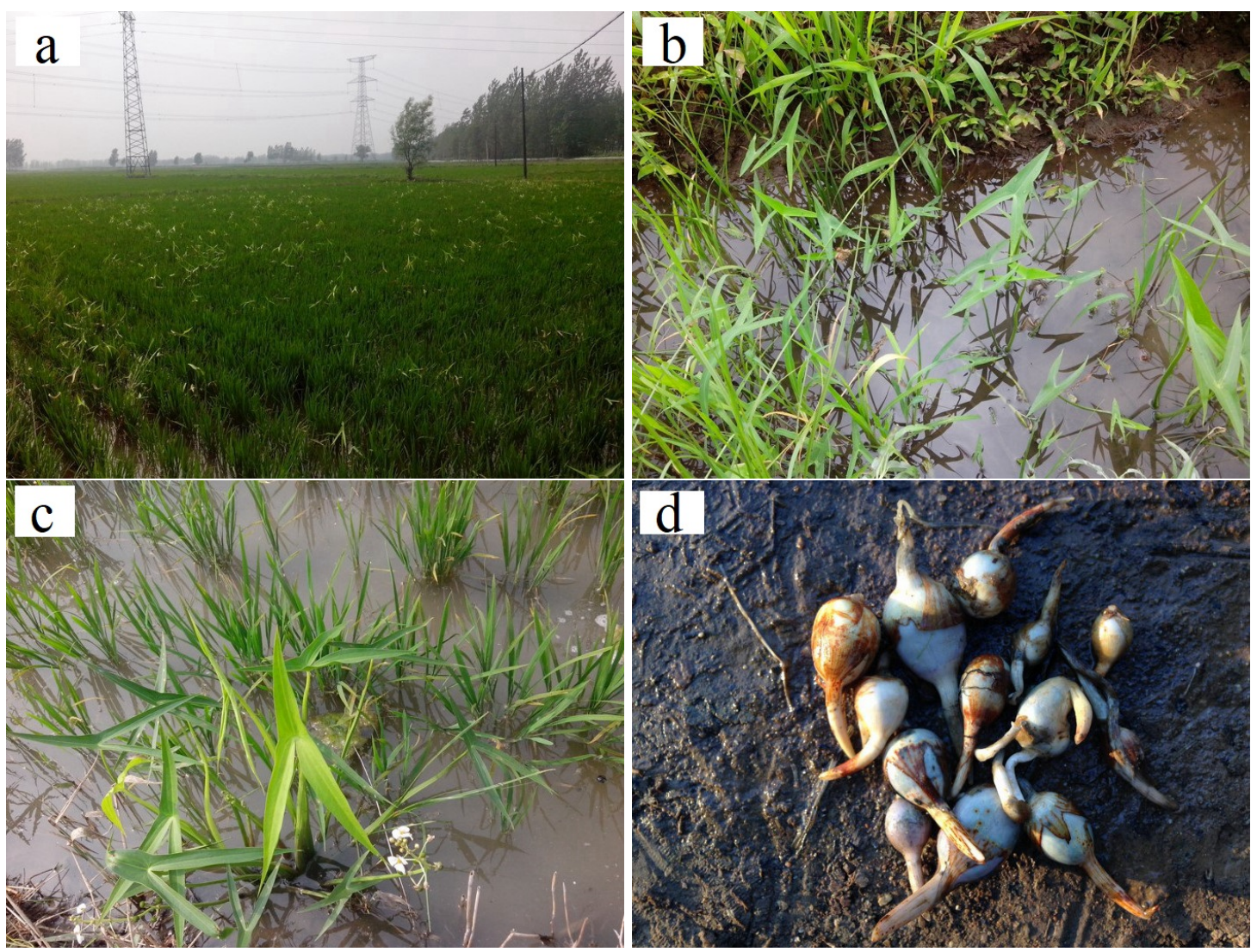

Fig. S1 The occurrence of S. trifolia in the rice paddies of China. (a) Growing conditions; (b) leaves; (c) flowers; and (d) corms. 